\title{
Populism in Italy: Cognitive Aspects
}

\section{Massimiliano Ruzzeddu', Marino D'Amore ${ }^{2}$ mruzzed@hotmail.com}

1) Tenured Researcher in Sociology, University Niccolò Cusano in Rome.

2) Master Lecturer and Ph.D. candidate in geopolitics and geoeconomics, University Niccolò Cusano in Rome.

\begin{abstract}
Like many others social phenomena, "populism" is a complex notion. By this we mean a notion showing a multiplicity of possible meanings. As a matter of fact, as we will see later, many are the definitions of populism, each based upon a different theoretical framework and/or scientific backgrounds. This complexity only increased following the recent electoral success of a number of parties and candidates, both in Europe and in USA, that massmedia and public opinions have labelled as "populist," even if those forces and candidates do not consider themselves to be populist. Consequently, it has become much harder to find objective and shared criteria for recognizing cases of populism. To address this dearth, in this first part of the work, we take into consideration the main definitions of populism, and the corresponding theoretical approaches, in order to draw an operational definition that we then apply to the second part of this essay. After this, we discuss the different representations of the people and the different kinds of populism that they generate.
\end{abstract}

* Keywords: populism, Italian politics, political culture. 


\section{Some Definitional Attributes of Populism}

In order to comprehend the diversity of definitions of populism, the first step is to trace the word's etymology. The word populism stems from the Latin word populus, which stands for "people." As a consequence, referring to populism means referring to phenomena and/or notions related to a national people. Within this framework, the meaning of populism should not be different from "democracy," as the word demos has a similar meaning, in ancient Greek, as populus. However, in the word populism the equivalent of the second term "-cracy" is missing and perhaps this is what makes the difference between the two words. So, the word democracy refers to any regime where mechanisms exist of transmission of the popular will. On the contrary, the suffix "-ism," in the word populism, refers to a choice of adherence to a given value. As a consequence, adding the suffix "-ism" to the word people entails value considerations rather than the description of an effective condition. In other words, the word populism is not supposed to describe an actual situation, but an attitude, pertaining to a representation of politics, which only should refer to "the people," whose interest is supposed to be the unique and only aim of any political class.

It is also important to highlight how the notion of populism is not descriptive, for it refers to the utopic ideal that politicians neglect particularistic interests and only care for general good. More exactly, it is possible to assess that most of the malcontent related to populist movements rests on the fact that political élites always need to choose a social layer to support, to the detriment of other social actors. Said differently, populism rests upon the "idea of the single, homogeneous, authentic people" (Müller, 2016, 10). As a matter of fact, populism generally depicts particular interests as pure corruption, and it "will engage in occupying the state, mass clientelism and corruption, and the suppression of anything like a critical civil society" (Müller, 2016, 173).

As a conclusion of this introduction, it is necessary to highlight how populist narrations always refer to given social groups, which more than others are undergoing the consequences of severe economic changes (Pasquino, 20). Populism is related to malcontent and social strains and can be the proper cognitive reference for those social actors who feel marginalized and need a more effective representation of the current reality, a representation providing them with reliable explanations for their condition, criteria for defining responsibility for their condition, and an orientation for their actions.

\section{Theoretical Approaches to Populism}

Within the above framework, however, it is necessary to take into consideration the numerous theories on populism existing in the scientific literature, in order to draw an operational definition fitting to our aim in this paper. The first relevant fact is that the number of articles and other kinds of scientific works on the subject is so huge that it is -needless to say- impossible to consider them all. Thus, in order to provide a working theoretical framework for populism we consider the main theoretical approaches, which do include most of the scientific works existing on populism.

\section{The Evaluation of Populism}

The first theoretical distinction is about the evaluation of populism. Even though scientific works should be free of personal evaluation, almost one century ago, Weber showed that personal opinions always affect investigations, and populism is not alien to this trend. As a consequence, it is almost impossible to find scientific works concerning populism whose 
authors do not show any judgmental attitude. This is understandable given the complexity of the notion of populism, and we therefore do have works that consider populism from a positive point of view.

Aside from the unavoidable challenges that populism poses to contemporary political life, one can consider it as the practical application of the democratic rule of the majority will. According to a Tocqueville-based theoretical framework, most theoreticians from the United States (Mudde and Kaltwasser, 2017, 1 ff.) stress the fact that what appears to be populism is often just the majority's decision, taken according to democratic rules. According to this point of view, populism (consisting of the people's will) performs the function of maintaining a strict relationship between masses and ruling élites (Crick, 2005, 626). No matter how irrational this decision appears, it needs to be respected especially when it clashes against the interests of "the landlords, the bankers, the bureaucrats, the priests, the elite, the immigrants and, most popular of all for populists to denounce, the politicians" (Ibid.).

Relevant in this category is the work of Ernesto Laclau. As a matter of fact, he matches the rise of the notion of populism with the early phases of sociological theory, which principally focused on the role and functions of the masses in the Western social and political life in 19th century. Well, in his opinion, the little prestige that characterizes the notion of populism among intellectual communities is related to the slight worry with which Tarde, Le Bon etc., described the rise of crowds as main actors in the last hundred years. The fear for the ultimate predominance of the disruptive homogenization forces that the crowds were embodying, brought the whole intellectual community in Europe to embrace "an identical prejudice - that is, the repudiation of the undifferentiated milieu which is the 'crowd' or the 'people' in the name of social structuration and institutionalization" (Laclau, 63). Therefore, in Laclau and collaborator Chantal Muffe's opinion, the negative meaning that the word populism has assumed in the recent scientific debate, depends on an intellectual habit, consisting of neglecting--let alone despising--crowd phenomena which show low levels of structuration.

In his attempt to amend this "distorted" representation of mass phenomena, Laclau identifies populism with a cognitive process of popular identity building, which is more likely to succeed if structural crises arise (Laclau, 178). Namely, populism emerges when given peculiar interests--especially from the middle-low layers of a society--are represented as "universal," i.e., communication patterns arise, which consider local interested as "popular interests" (Laclau, 183). Within this framework, he considers as examples of populism historical phenomena that other scholars would not, such as the political success of the Italian Communist Party (Laclau, 182), Mao Tze-Dong's Long March (Laclau, 122) or de Gaulle's reforms in the 1950s (Laclau, 177).

In other words, according to Laclau, the fuzziness of the word populism permits scholars to include in this scientific category phenomena which do not represent a challenge for the social system's stability, together with other phenomena--Le Pen, Bossi, M5S, Brexiters, etc.--which habitually are classified as populism. On the contrary, negative representations of populism rely on just this latter category of phenomena. As Stijn van Kessel (2015, 2; see also Mudde 2007; De Cleen, and Stavrakakis, 2017; Stavrakakis et al. 2017) has noted, in "the European context, populism is habitually associated with xenophobic politics and parties of the extreme or radical right (and therefore considered to be dangerous)." As a matter of fact, as we will see later, many populist parties have been arguing the need for a stronger popular sovereignty, as well as the representations of peoples they have produced, very often based upon an ethnic criterion. Furthermore, the foes of popular sovereignty are not only the political élites that have permitted the process of globalization--which, in the populist representation, has heavily reduced workers' welfare and citizens' rights--but also 
migrants and refugees, who are supposed to endanger natives' identities and traditions. The consequences might be--and have been at times--episodes of violence and discrimination towards ethnic minorities (as well as other kinds of minorities, such as homosexuals and Jews) and policies of border closure to migration and trade, whose economic consequences can be quite severe.

In terms of economies, the main feature of populism is irresponsibility. Even though just a few authors stress this character-with many attributing this character mainly to Latin America (Mudde and Kaltwasser, 2017 p. 3)--populist political programmes, characterized by economic irresponsibility, have been spreading all across Europe. Economic irresponsibility is mostly related to what Cas Mudde and Cristóbal Rovira Kaltwasser $(2013,158)$ have defined as "inclusionary populism" (while exclusionary populism consists of xenophobic and nationalistic programs). The phrase "inclusionary populism" refers to the open rejection of any hypothesis of public expense control, due to public budget limits; this phrase is based upon the belief in a Nation-state that promotes an equalitarian society. Even if Mudde and Kaltwasser have stated that inclusionary populism is typical of Latin America, rather than Europe, in front of the wide areas of economic disease that have been enlarging in many parts of Europe, inclusionary populism has begun characterizing the political agendas of a few populist parties, especially in Southern Europe, as we will see later.

\section{The Nature of Populism}

Besides evaluation, another distinction criterion is the nature of populism. Two theoretical mainstreams exist here: populism as a political practice and populism as a cognitive tool. The first considers populism as "a folkloric style of politics, which leaders and parties employ to mobilize the masses" (Mudde and Kaltwasser, 2017, 4 ff.). This definition especially refers to the informal attitude of a number of political leaders. Casual outfits and unceremonious--if not vulgar--language are part of a strategic communication aiming at representing a tighter closeness with the people, in opposition to the élites still linked to behavioural codes not belonging to the real life (see also Schmuck, et al. 2017, 88-89; Hammelers, et al., 2917, 141; Tarchi, 2015, 278).

However, one of the most interesting theoretical approaches for populism is what we can define as "cognitive." Large parts of the scholarship, in fact, sees populism as a way for diverse categories of social groups to describe and give sense to the globalized world. In other words, populism seems to be performing one of the main functions of ideology (see Eagleton, 1991; Hawkes, 1996, Jost, et al., 2009): providing actors with the cognitive tools for interpreting the world. Very interesting, from this point of view, is the definition of populism as an example of "thin ideology." A large number of scholars highlight the fact that populist parties have always incomplete representations of the world. This "means that it is unable to stand alone as a practical political ideology: it lacks the capacity to put forward a wideranging and coherent program for the solution to crucial political questions" (Stanley, 2008, 95).

In contrast to a "thin ideology," consider Marxism, which not only gave clear indications how to evaluate social and economic inequality and the ways to overcome this inequality-abolition of private property--through the lens of historical materialism, each social fact, no matter if cultural, political economic etc., could be explained. Well, populism cannot provide such a complete and coherent vision of the world. As we are going to see below, populism only defines a little number of core concepts; should that not be sufficient for explaining any social or political facts, populism is habitually able to "borrow" concepts from other ideological frameworks. 
This character does explain the unavoidable fuzziness of populism, i.e. the difficulty of assessing criteria for objectively classifying any fact either as populism or non-populism; on the other side, though, it would be possible to assess that this character also explains the extraordinary rapidity with which populism has been spreading around larger and larger masses in a lot of democratic countries. As a matter of fact, just this strong capability of borrowing concepts from different ideological settings has made of populism a representation of the world, to which a large number of people with diverse cultural and political problems can adhere without any problem (see Grillo in Italy, Verbeek, and Zaslove, 2016, 307). In spite of its superficiality--or maybe just because of this superficiality--populism looks like the ideological attitude that best fits to an epoch where the rate of social change has turned incredibly rapid, and where the ideological identities have turned incredibly evanescent.

\section{Core Concepts}

We said that populism is a complex concept because of the wide range of definitions and theoretical approaches. However, complex never means pure ignorance or unpredictability; rather, each complex phenomenon always characterizes ordered and stable elements. In the case of populism, the ordered part consists of a few core concepts that appear in each populist rhetoric: the people and the élites (Mudde and Kaltwasser, 2017, 9; Abts and Rummens, $2007,408)$. The centrality of the notion "people" is actually the reason why populism is to be considered as a representation of the world, rather than a political practice. As a matter of fact, "people" is always a social representation, whose features are strictly related to wider visions of the world. As Mudde and Kaltwasser $(2017,9)$ argue "that it is exactly the fact that 'the people' is an 'empty signifier' that makes populism such a powerful political ideology and phenomenon." So, people can refer to "common persons" (Elchardus and Spruyt, 2016, 113; Mudde, 2004, 545), as well as the native citizens of a given society (Abts and Rummens, 2007, 409; Mudde and Kaltwasser, 2017, 11; Stanley, 2008, 105; De Cleen, and Stavrakakis, $2017,3)$. Nevertheless, different notions of people can raise different declinations of populism; as a matter of fact, the word people can have two meanings--which can overlap each other.

On one side, we have representations of people as the pure part of the society, in opposition to the economic and moral corruption of rulers, politicians, intellectuals, financial groups, etc. This meaning of the word people denotes the honest individuals who labor every day to achieve their socially acceptable goals: having a family, raising children, buying their own home, etc. Needless to say, populism represents those projects as threatened by the greed and cynicism of national and international élites who are depriving the people of their legitimate sovereignty (Kenny, 2017, 2; De Cleen, and Stavrakakis, 2017, 4; Crick, 2005, 8; Stanley, 2008, 102; Mudde and Kaltwasser, 2013, 151), their rights, and their wealth. Such a representation of the people is leading to political discourses that focus on popular sovereignty, restoration of "true" democracy, and--needless to say--social politics more favorable to lower classes.

On the other side, the word people refers to specific ethnic/national groups, habitually the largest ethnic group in a given country. The populist parties that refer to this kind of representation of the people habitually lobby for stricter migration policies and border closure. Generally, this kind of populism depicts a condition of peril for their own countries due to the massive access of large migrant communities whose diversity is jeopardizing--in their opinion--local traditions, identities and social fabric ${ }^{1}$ (Reinemann et al., 2017, 18; Norocel 2017, 47; Kenny, 2017, 9; Verbeek and Zaslove, 2016, 314; Krämer, 2017, 1301).

\footnotetext{
$\overline{1} \quad$ It is worth noticing that, in the studies on specific European countries, hostility towards immigration appears in the political discourses of all populist parties. See Aalberg et al. 2017 and van Kessel, 2008.
} 
The other basic element of the populist representations is the élite. Populism always depicts élites as a bunch of corrupted individuals who are using their position to grant privileges for themselves and their friends at the expenses of the people. This representation offers an easy explanation for the disease that large parts of middle-lower classes have been facing in the last decade; financial turbulences and economic crisis are, in their opinion, just a tool to hide élites' plans (even better, conspiracies) to deprive common people of their wealth and political power (Tarchi, 2015, 280).

Most literature highlight the Manichean character of populism (Mudde and Kaltwasser, 2017, 97), with people and élites always seeming to clash against each other (Mudde and Kaltwasser, 2017, $11 \mathrm{ff}$.$) . As Mudde (2004) states:$

\begin{abstract}
Essential to the discourse of the populist is the normative distinction between "the elit"' and "the people," not the empirical difference in behavior or attitudes. Populism presents a Manichean outlook, in which there are only friends and foes. Opponents are not just people with different priorities and values, they are evil! Consequently, compromise is impossible, as it "corrupts" the purity (544).
\end{abstract}

Needless to say, the right side is the one of the people, while élites bring corruption and decadence. Namely, in populist narrations, élites are allegedly responsible for the poverty of the lower classes, for security problems in the cities, and for the so-called loss of people's cultural identity. As a matter of fact, the most relevant phenomena of the last years, especially when financial crisis and mass migration are considered, the populist vision of the world sees troubles as the result of intentional political choices that élites have taken in the name of little groups' interests, rather than in the general welfare. Within this framework, populism depicts globalization as a strategy for depriving (Western) masses of their political and economic rights, on behalf of few capital holders, who can invest where the labor is the cheapest. Even migration is watched from this point of view; the mainstream opinion considers it, if not a clear strategy for ethnic suppression, as least as a phenomenon to be tolerated, in order to lower the labor cost. Bad representations of élites also belong to populist nationalism, with migration being due to the incapability of rulers to control national borders and to oppose to the international bodies (ONU, UE etc. ), which are allegedly imposing hospitality policies to single states (Fitzgibbon and Guerra, 2010, 276; Thompson, 2017, 52). Even further, there are the claims that actual political projects are in progress to change the ethnical identity of a given country.

\title{
Operational Definition of Populism
}

It is evident from the above that providing a clear definition of populism would add nothing new to the scholarship on this subject. Each additional definition of a complex phenomenon such as populism would either exclude some cases or lack clear criteria of case inclusion/exclusion from this category. Therefore, in order to draw an operational idea of populism, we will rely on the above-mentioned core notions, and will consider populism as a representation of the world, which states that a number of élites, who are pursuing particular interests, are depriving the people of their rights and wealth.

It is important to highlight the cognitive function of populist representations of reality (Reinemann et al 2017, 19-20); as we stated earlier, populism provides an explanation for the main manifestations of globalization that have been affecting middle-low classes, especially financial crisis and migration (very low are the references to other global issues such as 
global warming or terrorism). Generally speaking, the contemporary success of populism can be explained by the fact that it provides the public with a sense of reality in a world that appears every day more complex, ${ }^{2}$ and where increasing numbers of social actors have troubles finding their own identity, and related action strategies, in a globalized word.

\section{Populism in Italy}

We have so far focused on the cognitive side of populism since we believe it is the best approach to study Italian populism, given that populism is so deeply rooted in Italian culture. In other words, while Tangentopoli swept away the traditional political system in the 1990s, the reason why populist forces have often prevailed afterwards is that their representation of the world fits with the deepest roots of Italian political culture. The need for palingenetic purification, which is typical of populist communication, does fit with the deepest representation of time in a Catholic country just like Italy. Before dealing with the reasons of this phenomenon, we are going to take some space to describe Populism's rise in Italy.

\section{Brief Review of the Rise of Populism in Italy}

As Manuel Anselmi (2018, 66 ff.; Anselmi, De Nardis 2018, 2) shows, Italy is the country, among the Western democracies, where populist parties achieved major success. According to his classification, we are going to take into consideration the three principal Italian populist parties: Forza Italia, Lega Nord, Movimento 5 Stelle. The political analyst Marco Tarchi (2003) reconstructs the events of populism in Italy, where the moments of mistrust in politics and therefore of creating fertile ground for such a solution took place immediately after the Second World War and then, after half a century, with the denunciation of the corruption of the political system following the inquiries of Mani Pulite (Clean Hands): the so-called Tangentopoli. The investigation, led by Antonio Di Pietro, who erased the first republic, subverting dynamics and political balance that had persisted for half a century, stimulating the populist wind that would split, over time, into more trickles, into very different components but at the same time united by the same need for redemption and rehabilitation of Italian politics. Forza Italia was born as an answer to this need, immediately embodying a clear identity that focuses on the figure of the leader, a personalistic and centralizing character that generates the so called Berlusconism, an externalization of a "media neo-populism" that uses the strength of the communicative element as its means of diffusion.

La Lega Nord (Northern League), on the other hand, has represented another declination of the populist phenomenon, exacerbating some elements placed as thematic corollaries of its intrinsic essence: the deep territorial rooting, the profound sense of belonging combined with an evident symbolism, which excludes otherness and it is self-celebrating as metastate, revealing a divisive and separatist intentionality. To these realities was later added the "grillismo" of the Movimento 5 stelle (5-star Movement), which represents a further evolution of the above-mentioned phenomenon, because it makes the Network the main communication channel of its own political verb, updating a political-populist continuum cadenced by the technological innovation of the vehicle of the communicative one, which becomes first digital and then real aggregation.

Within such an understanding, we analyze the election results of these parties taking into consideration the votes received in the Chamber (House of Commons). The reason for this choice lies both in a merely numerical factor. Its electoral pool is much broader than

$\overline{2}$ Within this framework, little robust appear those explanations of populism, which rely on strictly economic reasons, namely middle-low classes' malcontent for the consequences of financial crisis. 
the one in the Senate, also because the voting methods for the latter have changed over the years, eliminating the possibility of dealing uniformly with the evolution and the progress of the consultations,

Table 1: House vote history in percentages (Source: https://elezionistorico.interno.gov.it/)

\begin{tabular}{|l|c|c|c|c|c|c|c|}
\hline \multicolumn{1}{|c|}{ Partito } & 1994 & 1996 & $\mathbf{2 0 0 1}$ & $\mathbf{2 0 0 6}$ & $\mathbf{2 0 0 8}$ & $\mathbf{2 0 1 3}$ & $\mathbf{2 0 1 8}$ \\
\hline $\begin{array}{l}\text { Forza Italia/Popolo } \\
\text { delle Libertà }\end{array}$ & 21,01 & 20,57 & 29,42 & 23,72 & 37,38 & 21,56 & 14,00 \\
\hline Lega Lombarda & 8,36 & 10,07 & 3,94 & 4,58 & 8,30 & 4,09 & 17,35 \\
\hline Movimento 5 Stelle & & & & & & 25,56 & 32,68 \\
\hline
\end{tabular}

In March 1994, Forza Italia imposed itself with 21.01 percent and 30 seats and the League stood at 8.36 percent with 11 seats. In the following political consultations of 1996 where Forza Italia reached 20.57 percent gaining 37 seats while the League reached 10.07 percent with 20 seats. 2001 saw again the victory of the center-right, in the Chamber Forza Italia reached 29.43 percent with 62 seats.

The aforementioned alternation turned into a real separation in 2006 , when the catalytic effect of the populist push faded, following a sinusoidal trend, and the electoral outcome gave Italy two deeply divided and conflicting countries, as witnessed by the opposite results of the two chambers, where every reformist and planning dynamism gave way to a substantial stagnation and to a clash that would lead nowhere. In fact, in the Chamber Forza Italia it reached 23.72 percent of the votes with 137 seats, the League at 4.58 with 26 seats. The coalition reached a total of 277 seats relegating them to the opposition.

At the April 2008 consultations, at the Chamber, il Popolo delle Libertà collected 37.38 percent of the votes with 272 seats and the League reached 8.30 pecent with 60 seats.

The situation changed again at the 2013 consultations. The scandals and the legal vicissitudes that involved the outgoing premier, affecting his political credibility, were joined by the entry into the political arena of a new exporter of a different populist model: il Movimento 5 stelle (the 5-star Movement). The latter acted as a grouper of undecided voters, taking advantage of the obvious hemorrhaging of votes that had hit the center-right. This conjuncture of events placed him in the political scene as a credible interlocutor, a new populist reality that conveyed the democratizing demands of the Net, revealing itself as the anti-politics that rises to the institutional role of real politics. A maturation process that will be completed in 2018. In the Chamber il Popolo delle Libertà reached 21.56 percent with 97 seats, la Lega at 4.09 percent with 18 seats, reaching a total of 124 with the coalition to which they belong. The party of Beppe grillo instead reached 25.56 percent of the votes with 108 seats. A path that, as mentioned, found its maturation in 2018. In fact, this was the year of the definitive consecration of the movimento pentastellato ( 5 star movement) as the first political force in the country, an official investiture that irreversibly transformed what was born in reality as an anti-politics, determined to remove the anachronistic clientelisms of the first two republics, but later forced to deal with the complex institutional dynamics. A new populism, definitely mediatic, to paraphrase Umberto Eco, which clashed with the sovereign one of the League, which, in this election, turned the hierarchical balance of its first coalition upside down, 
becoming its leading party. At the Chamber the pentastellato movement collected 32.68 percent of the votes with 133 seats, La Lega 17.35 percent with 73 and Forza Italia 14.00 percent with 59 , with a clear reversal of the balance in the center-right area mainly due to exploitation of migratory flows in a profoundly changed geopolitical scenario.

\section{Italian Political Culture}

Already in 1963, Gabriel Abraham Almond and Sidney Verba stated that "the picture of Italian political culture that has emerged from our data is one of relatively unrelieved political alienation and of social alienation and distrust" (Ibid., 402). Many and diverse are the causes of this phenomenon. Namely, until the country unification (19th century), a high number of invasions and political regimes occurred: Therefore, a belief in its impotence have provoked a deep mistrust of the secular state and, generally, of all public institutions. The State has become a stranger entity, unable or unwilling to represent its citizens or to foster any idea of general good. This has deeply weakened the feelings of identification with secular institutions, whether representative of local authorities or foreign, occupying countries (Ibid., 403). As a consequence, public opinions' feeling is that any public decision is only meant to defend the élite interests, and disobedience is always legitimate (unless heavy sanctions are likely to follow). In other words, in the modern era a gap arose between Italy and the rest of Europe, especially when the Reformation established a strong link between communities and local authorities (the principle of cuius regio, eius religio) and the Westphalia Treaties -in France, Great Britain, and Spain- gave birth to the idea of the nation state, made up of individuals tied to each other by the link of citizenship, rather than by local-familiar ties (Bansfield, 1958; Foot, 2003, 28).

Furthermore, it is worth noticing that, in the last two millennia, the Catholic Church laid with no interruption over the Italian territory stable and exercised political and moral authority over the whole country. This has deeply affected the Italian culture, by creating a sort of 'religious ground bass' (Bellah, 197, 440; Alberoni, 1974, 470), which is still affecting contemporary Italian politics in spite of the achievement of unification and the democratic, secularist juridical order in force (Ginsborg, 2003, 85 ff.). As a matter of fact, Italian representations of the world, still show universalistic and metahistorical characters, that fit to the universalistic and millenarian scope of the Catholic narrations. Namely, the representations of social change often consist of apocalyptic and worldwide events: change is always a violent trauma, rather than a process.

This influence is particularly evident in contemporary populist politics. Although the fields of conflict are always about merely Italian issues (workers' rights, welfare state etc.), populist representations refer habitually to a wider range of causes, most of which are beyond national borders, such as global capitalism; similarly, Italian populism never aim to change a single social issue: in their view, any relevant local transformation is only possible within the framework of a radical subversion of the socio- economic system at a supranational -if not worldwide- level.

\section{Conclusions}

As we have shown above, since 1994, Populist parties have been gained in Italy at least 25 percent at each electoral competition. In spite of this, no populist policy has ever been implemented in Italy. Populist forces have held government responsibilities but very few changes have occurred in the Italian-decision making structure. The Constitution is unchanged and so are the country's international relationship. No major changes have 
occurred in the taxation system and the labour market (the main issues of populist electoral programs). In spite of this, populist forces have remained among the most popular in the country.

This is may be the best evidence of the cognitive nature of populism. Different from the 20th century ideologies, populism does not rely on material and economic interests; contemporary populism is rather more the expression of what Niklass Luhmann (1989, 17) "describes as a discrepancy between the complexity of the actual world and the consciousness capability for apprehension or communication." In other words, the current epoch is characterized by high levels of social complexity. Populism can be considered as the attempts of individual consciousness to grasp this complexity through simplified representations of reality. 


\section{References}

Abts, Koen and Rummens, Stefan. "Populism versus Democracy." Political Studies. Volume 55, Issue 2 (2007), 405-424.

Alberoni, Francesco. 'Carisma d'ufficio e movimenti spontanei'. Cavazza F. and Graubard, S. (Eds), I/ caso italiano, Milano, Garzanti, 1974

Almond, Gabriel Abraham and Sidney Verba, The Civic Culture: Political Attitudes and Democracy in Five Nations. Princeton University Press, 2015. Project MUSE muse.jhu. edu/book/43668. (First publication: 1963)

Anselmi, Manuel. Populism: An Introduction. London-New York: Routledge (2017).

Anselmi, Manuel and De Nardis Fabio, "Italian politics between multipopulism and depoliticization." Revista Internacional de Sociología RIS vol. 76 (4), e111, octubrediciembre (2018).

Banfield, Edward. C. The Moral Basis of a Backward Society, with Laura Fasano. Glencoe, IL, The Free Press, 1958.

Bellah, Robert. 'Le cinque religioni dell'Italia moderna'. Cavazza F. and Graubard, S. (Eds), I/ caso italiano, Milano, Garzanti, 1974.

Crick, Bernard, Professor Sir. 'Populism, politics and democracy'. Democratization, 12:5 (2005), 625-632, DOI: 10.1080/13510340500321985.

De Cleen, Benjamin and Stavrakakis, Yannis. 'Distinctions and Articulations: A Discourse Theoretical Framework for the Study of Populism and Nationalism'. Javnost - The Public (2017). DOI: 10.1080/13183222.2017.1330083.

Eagleton, Terry. Ideology: an introduction. London: Verso, 1991.

Elchardus, Mark and Bram Spruyt. 'Populism, Persistent Republicanism and Declinism: An Empirical Analysis of Populism as a Thin Ideology'. Government and Opposition, Vol. 51, No. 1, pp. 111-133, 2016 doi:10.1017/gov.2014.27. First published online 30 September 2014.

Fitzgibbon, John and Guerra, Simona. 'Not Just Europeanization, Not Necessarily Populism: Potential Factors Underlying the Mobilization of Populism in Ireland and Poland' Perspectives on European Politics and Society, 11:3 (2010), 273-291, DOI: 10.1080/15705854.2010.503033.

Foot, John. Modern Italy, Basingstoke, Palgrave, Macmillan, 2003.

Ginsborg, Paul. Italy and its discontents : family, civil society, state 1980-2001, London. Penguin Books, 2003.

Hammelers Michael, Bos Linda and de Vreese Claes. 'The Netherlands. A heartland full of insights into populist communication'. In AAlberg Toril, Esser Frank, Reinemann Carsten, Strömbäck Jesper and de Vreese Claes H. (eds) Populist Political Communication in Europe. New York: Routledge, 2017.

Hawkes, David. Ideology. London, Routledge, 1996.

Kenny, Michael. 'Back to the populist future?: understanding nostalgia in contemporary ideological discourse'. Journal of Political Ideologies (2017). DOI: 10.1080/13569317.2017.1346773.

Krämer, Benjamin. 'Populist on-line practices: the function of the Internet in right-wing populism, Information'. Communication \& Society, 20:9 (2017), 1293-1309, DOI: 10.1080/1369118X.2017.1328520.

Jost John T., Napier Jaime L. and Federico Christopher M. 'Political Ideology: Its Structure, Functions, and Elective Affinities'. Annual Review of Psychology, 60 (2009), 307-337. DOI: 10.1146/annurev.psych.60.110707.163600. 
Laclau, Ernesto. On populist reason. London: Verso, 2005.

Luhmann, Niklas. Ecological Communication. Polity Press, Great Britain, 1989.

Mudde, Cas. 'The Populist Zeitgeist'. Government and Opposition. Vol. 39 Iss. 3 (2004). DOI: 10.1111/j.1477-7053.2004.00135.x.

Mudde, Cas and Kaltwasser, Cristóbal Rovira. 'Exclusionary vs. Inclusionary Populism: Comparing Contemporary Europe and Latin America'. Government and Opposition, no 48 (2013): 147-174 doi:10.1017/ gov.2012.11.

Mudde, Cas and Kaltwasser, Cristóbal Rovira. Populism: a very short introduction. New York: Oxford University Press, 2017.

Müller, Jan-Werner. What is populism? Pennsylvania, PA: University of Pennsylvania Press, 2016.

Norocel, Ov Cristian. 'From agrarian to right-wing populism'. In AAlberg Toril, Esser Frank, Reinemann Carsten, Strömbäck Jesper and de Vreese Claes H. (eds) Populist Political Communication in Europe. New York: Routledge, 2017.

Pasquino, Gianfranco. 'Populism and democracy'. In Albertazzi, Daniele and McDonnel, Duncan, eds. Twenty-First Century Populism: The Spectre of Western European Democracy. Houndmills, Basingstoke, Hampshire: Palgrave Macmillan, 2008.

Reinemann Carsten, Aalberg Toril, Esser Frank, Strömbäck Jesper and de Vreese Claes. 'Populist political communication. Toward a model of its causes, Forms and effects'.

In AAlberg Toril, Esser Frank, Reinemann Carsten, Strömbäck Jesper and de Vreese Claes H. (eds) Populist Political Communication in Europe. New York: Routledge, 2017. Schmuck Desirée, Matthes Jörge and Boomgaarden Haio. 'Austria. Candidate-centered and anti-immigrant right-wing populism'. In AAlberg Toril, Esser Frank, Reinemann Carsten, Strömbäck Jesper and de Vreese Claes H. (eds) Populist Political Communication in Europe. New York: Routledge, 2017.

Stanley, Ben. 'The thin ideology of populism'. Journal of Political Ideologies, 13:1, (2008) 95110, DOI: 10.1080/13569310701822289.

Stavrakakis, Yannis, Giorgos Katsambekis, Nikos Nikisianis, Alexandros Kioupkiolis, and Thomas Siomos, "Extreme right-wing populism in Europe: revisiting a reified association," Critical Discourse Studies, 14:4 (2017), 420-439, DOI: 10.1080/17405904.2017.1309325. Tarchi M.,L' Italia populista. Dal qualunquismo ai girotondi, II Mulino, Bologna, 2003.

Tarchi, M. 'Italy: the promised land of populism?'. Contemporary Italian Politics. 7:3, (2015) 273-285, DOI: 10.1080/23248823.2015.1094224.

Thompson, Grahame F. 'Populisms and liberal democracy - business as usual?'. Economy and Society, 46:1 (2017), 43-59. DOI: 10.1080/03085147.2017.1307652.

Van Kessel, Stijn. Populist Parties in Europe: Agents of Discontent? Houndmills, Basingstoke, Hampshire: Palgrave Macmillan, 2015.

Verbeek, Bertjan and Andrey Zaslove, "Italy: a case of mutating populism?" Democratization, no 23:2 (2016), 304-32. DOI: 10.1080/13510347.2015.1076213.

Urbinati, Nadia. "Democracy and Populism." Constellations 5 no.1 (1998): 110-24.

Yadudu, Auwalu. "Benefits of Sharia and Challenges of Reclaiming a Heritage." Paper Delivered at the Nigerian Muslim Forum, Commonwealth Conference Center, London, April 2001. 